\author{
VESNA LAZAREVIĆ ${ }^{1}$ \\ MIODRAG \\ STANISAVLJEVIĆ ${ }^{2}$ \\ ${ }^{1}$ Military Hospital Nis \\ ${ }^{2}$ High Technical School of \\ Professional Studies, Požarevac \\ ${ }^{1}$ vesna.toxicology@gmail.com
}

\section{ANALYSIS OF CRITICAL CONTROL POINTS IN MEAT INDUSTRY}

Abstract: The technology of meat processing involves the processes and operations which lead to the emission of harmful gases, wastewaters and sludge. In order to monitor more easily and to remove the possible causes, this paper analyses the critical points of the technology of meat processing as well as the consequences of undesired events, aiming at reducing the risk level.

Key words: meat industry, wastewater, critical control points.

\section{INTRODUCTION}

The technology of meat processing involves the processes and operations which run the risk of disturbing the quality of working and living environment. Therefore, what is needed is the analysis of the critical control points (CCP) in order to monitor more easily and remove the possible causes as well as the consequences of undesired events. To identify CCP it is necessary to have a good knowledge of the technological process.

\section{MEAT PROCESSING TECHNOLOGY}

The technology of meat processing includes the slaughter of cattle, meat preparation and meat processing. The procedure of stunning and bleeding out the animals, emptying, cleaning and washing the stomach and intestines, processing legs, hooves and horns is carried out in specialized space, which at the same time represents the most polluted part of the slaughterhouse. Natural cooling is performed at room temperature, whereas pre-cooling and cooling are done at lower temperature in special rooms. The transportation of slaughtered cattle is done mechanically using special tinned hooks, which move with the help of a transporter at particular height in the desired direction, from the moment of slaughtering, through certain processing phases to cold storage or further distribution.

Water is used in large amounts in the process of slaughtering, washing the slaughtered cattle and removing blood, fat and small pieces of meat and other waste. This means that this technological process is a big consumer, but at the same time a significant "producer" of wastewaters of organic origin.

Regardless of the fact what the aim of distribution is fresh meat consumption, meat processing or meat preservation, it is necessary to carry out the examination, cooling and storing of the meat. Preservation procedure involves exposing meat, fat tissue, intestines, skin, the remains of connective and fat tissue and added ingredients (additives) to heat in hermetically closed dishes (cans) after processing.

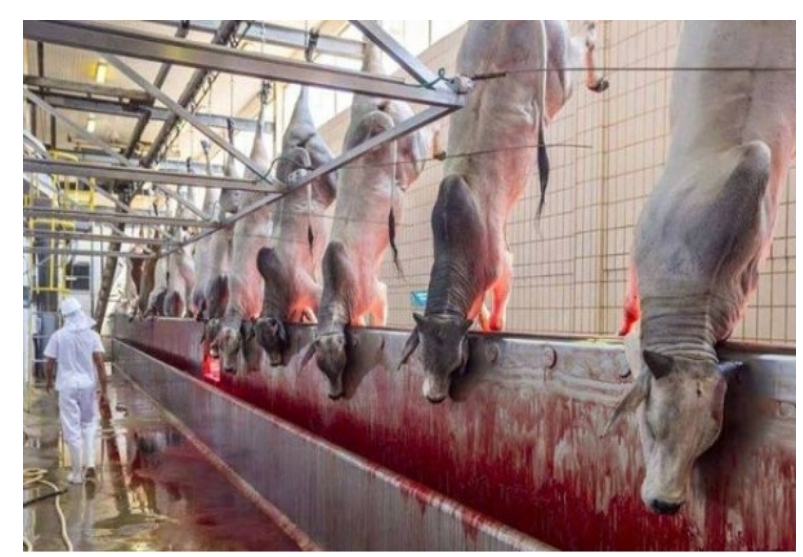

Figure 1. The technology of meat processing

Sterilization is a method of preservation in which meat products are exposed to high temperatures $\left(100^{\circ} \mathrm{C}\right.$ $130^{\circ} \mathrm{C}$ ) in hermetically closed containers.

\section{Defining critical control points in the technology of meat processing}

There are approximate data on pollution regarding the emission of blood of slaughtered animals into rivers. When it comes to food industry, meat industry is regarded as one of the biggest environment pollutants.

Wastewaters produced when slaughtering calves have ${ }_{20}^{\circ}{ }^{\circ} \mathrm{BPK}_{5} 800-1000 \mathrm{mg} / \mathrm{l}$, with water usage of 14001 per animal, whereas wastewaters produced when slaughtering pigs have $1000-2000 \mathrm{mg} / \mathrm{l}$, with water usage of $1000 \mathrm{l}$ per animal. On the basis of these data, without taking into consideration wastewaters from the other parts of meat production and processing, sludge 
disposal, emission of products of burning into the atmosphere, it is obvious that meat industry is one of the largest environment pollutants when we talk about food industry.

Working conditions in slaughter industry in most steps are characterized by working in wet, damp and dark rooms, with some workers doing their jobs outdoors. Working temperature in the rooms is from $+4^{\circ} \mathrm{C}$ to $+10^{\circ} \mathrm{C}$, with significant air circuit. Special microclimatic conditions apply in cold storage where the temperatures go from $-18^{\circ} \mathrm{C}$ to $-40^{\circ} \mathrm{C}$. Due to frequent entering and leaving cold storage, workers are exposed to sudden temperature changes.

In cold storage there is a danger of gases which serve to lower the temperature (ammonium, freon etc).

The danger of toxic chemicals is limited to light and occasional exposure to concentrated chemicals used as protective agents, such as borax, boric acid, natrium sulphate, nitrates and nitrites.

Noise is also present in this technological process, especially when using machines for cutting bones and meat, mincing meat, centrifugation etc.

While melting fat, thermal radiation appears and vapors of fat acids and acrolein are also produced.

In order to protect citizens as well as workers, what is needed is a high level of hygiene; therefore, working rooms should be designed and constructed to meet these requirements. Materials used for building these rooms must not easily absorb fat or water and should be easy to clean. All working rooms should be well lit with good ventilation system. Well maintained devices for washing sanitary fixtures (including showers where possible) should be put next to the working rooms, but separated by the space which is ventilated.

Emission of pollutants is present when meat is dried and it depends on several factors: the kind of wood used for burning, the amount of moisture in it, the amount of smoke in recirculation and others.

Hard particles, carbon-monoxide, aldehydes and organic acids are emitted into the atmosphere.

\section{Qualitative and Quantitative Characteristics of Wastewaters}

Qualitative characteristics of wastewaters for meat processing are organic types of pollution such as blood, proteins, fats, small particles of meat etc, whose contaminating effect is assessed by the parameters such as $20^{\circ} \mathrm{CBPK}_{5}$, HKP and suspended organic substances. The pollution of these wastewaters depends on the degree of blood recuperation, the size of a slaughterhouse and the way of fecal matter treatment.

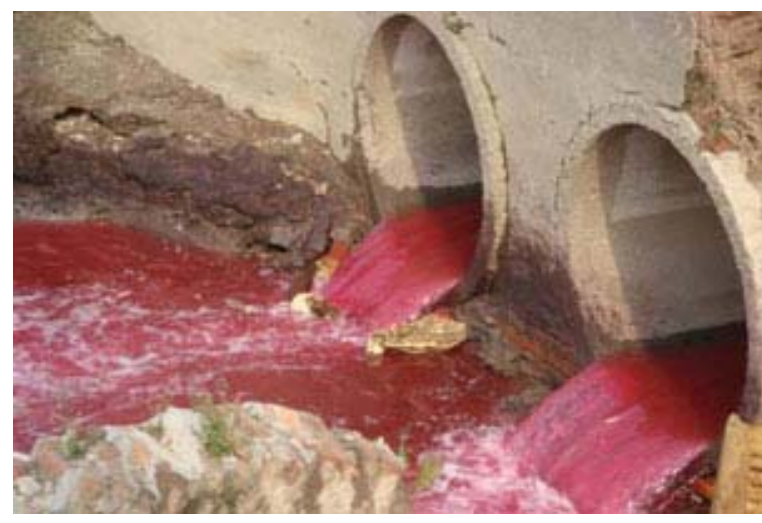

Figure 2. Wastewater meat industry

When processing and canning meat, the following should be taken into account:

- 3 to $5 \mathrm{~kg} 20^{\circ} \mathrm{CBPK}_{5} / \mathrm{kg}$ salted foods

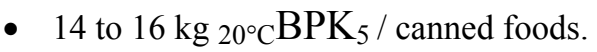

The amount of wastewaters varies depending on the ways in which fecal matter is treated, the size of slaughterhouses and the kinds of animals processed.

Table 1 shows the amount of wastewaters used in slaughterhouses depending on the kind of animals and the weight of the cleaned skeleton.

Table 1. The amount of wastewaters used in slaughterhouses depending on the kind of animals and the weight of the cleaned skeleton

\begin{tabular}{lccc}
\hline $\begin{array}{c}\text { Animals species which are } \\
\text { processed }\end{array}$ & Slaughterhouse & $\begin{array}{c}\text { Evacuation of fecal } \\
\text { matter }\end{array}$ & $\begin{array}{c}\text { The amount of wastewater per } \\
\text { kilogram skeleton }\end{array}$ \\
\hline Pigs and small animals & Small & Dry (without rinsing) & 81 \\
\hline Poultry & Big & With rinsing & $\begin{array}{c}10-131 \text { with water recirculation } \\
18-21 \text { l without water } \\
\text { recirculation }\end{array}$ \\
\hline Big animals & & Small & Dry (without rinsing) \\
\hline Big animals & Small & With rinsing & 51 \\
\hline Big animals & Big & Dry (without rinsing) & 151 \\
\hline Big animals & Big & With rinsing & 131 \\
\hline
\end{tabular}


Table 2 shows basic qualitative and quantitative characteristics of wastewaters of a referential slaughterhouse

Table 2. The quality of wastewaters of a referential slaughterhouse

\begin{tabular}{|c|c|c|}
\hline The measured parameter & Analyzed values & MPK \\
\hline Temperature of water $/ \operatorname{air}\left({ }^{\circ} \mathrm{C}\right)$ & $16,8 / 14 \pm 0,4$ & up to 40 \\
\hline Colour of water $(\mu \mathrm{m})$ & grey & - \\
\hline Smell of water & unpleasant & - \\
\hline $\mathrm{pH}$ & $7,4 \pm 0,02$ & $5,5-9,5$ \\
\hline Particulate matter by IMHOFF $\left(\mathrm{mg} \mathrm{dm}^{-3}\right)$ & $0,8 \pm 3 \%$ & 1 \\
\hline Suspended solids $\left(\mathrm{mg} \mathrm{dm}^{-3}\right)$ & $256 \pm 18 \%$ & 500 \\
\hline The residue after evaporation $\left(\mathrm{mg} \mathrm{dm}^{-3}\right)$ & $601 \pm 5 \%$ & - \\
\hline $\mathrm{C}_{\mathrm{Cl}}^{-}\left(\mathrm{mg} \mathrm{dm}^{-3}\right)$ & $42,5 \pm 4 \%$ & 450 \\
\hline $\mathrm{C}_{\mathrm{SO} 42^{-}}\left(\mathrm{mg} \mathrm{dm}^{-3}\right)$ & $33,2 \pm 4 \%$ & 350 \\
\hline $\mathrm{C}_{\mathrm{PO} 43}{ }^{-}\left(\mathrm{mg} \mathrm{dm}^{-3}\right)$ & $0,56 \pm 12 \%$ & - \\
\hline Detergents $\left(\mathrm{mg} \mathrm{dm}^{-3}\right)$ & $<0,025 \pm 6 \%$ & - \\
\hline Oil and grease $\left(\mathrm{mg} \mathrm{dm}^{-3}\right)$ & $10,05 \pm 18 \%$ & 30 \\
\hline $\mathrm{Fe}\left(\mathrm{mg} \mathrm{dm}^{-3}\right)$ & $0,15 \pm 3 \%$ & - \\
\hline $\mathrm{Cr}\left(\mathrm{mg} \mathrm{dm}^{-3}\right)$ & $<0,05 \pm 9 \%$ & 1 \\
\hline $\mathrm{Cu}\left(\mathrm{mg} \mathrm{dm}^{-3}\right)$ & $<0,02 \pm 2 \%$ & 1 \\
\hline $\mathrm{Ni}\left(\mathrm{mg} \mathrm{dm}^{-3}\right)$ & $<0,04 \pm 2 \%$ & 1 \\
\hline $\mathrm{Cd}\left(\mathrm{mg} \mathrm{dm}^{-3}\right)$ & $<0,05 \pm 5 \%$ & 0,2 \\
\hline $\mathrm{Zn}\left(\mathrm{mg} \mathrm{dm}^{-3}\right)$ & $<0,005 \pm 6 \%$ & - \\
\hline $\mathrm{Pb}\left(\mathrm{mg} \mathrm{dm}^{-3}\right)$ & $<0,1 \pm 3 \%$ & 0,1 \\
\hline
\end{tabular}

MPC - maximum permissible concentration

Technological Scheme of Wastewaters Purification Plant

Besides satisfying the change criteria in the production technology, which include blood recuperation and complete fecal matter treatment, picture 4 shows a technological scheme of a plant for pre-treatment of wastewaters from meat processing industry.

First, wastewaters are accumulated in the collection reservoir, which enables purification to have a continual course, then raw materials from the technological process are eliminated through a fine grid and taken to a container for sieved material, which is processed together with other waste matter from the technological production process in dog pounds. Wastewaters are taken to a reactor for intensive physical-chemical purification in which air floatation is performed by adding $\mathrm{Ca}(\mathrm{OH})_{2}, \mathrm{FeCl}_{3}, \mathrm{Al}_{2}\left(\mathrm{SO}_{4}\right)_{3}$ and ultrasteril which contains enough chloride for wastewaters disinfection.

In the container, the floated material is processed with other waste matters from the technological production process. Wastewaters purified in this way are taken to an aeration reactor with prior adjustment of $\mathrm{pH}$ $\mathrm{Ca}(\mathrm{OH})_{2}$, by means of which ammonium as a gas is completely eliminated, and afterwards an obligatory correction of $\mathrm{pH}$ using $\mathrm{H}_{2} \mathrm{SO}_{4}$ is performed.
The absorption of ammonium using $\mathrm{H}_{2} \mathrm{SO}_{4}$ is performed in a scrubber, by means of which we obtain $\left(\mathrm{NH}_{4}\right)_{2} \mathrm{SO}_{4}$, which can be used in agriculture and effluent - purified collective wastewaters from technological meat processing, which are poured into the sewage.

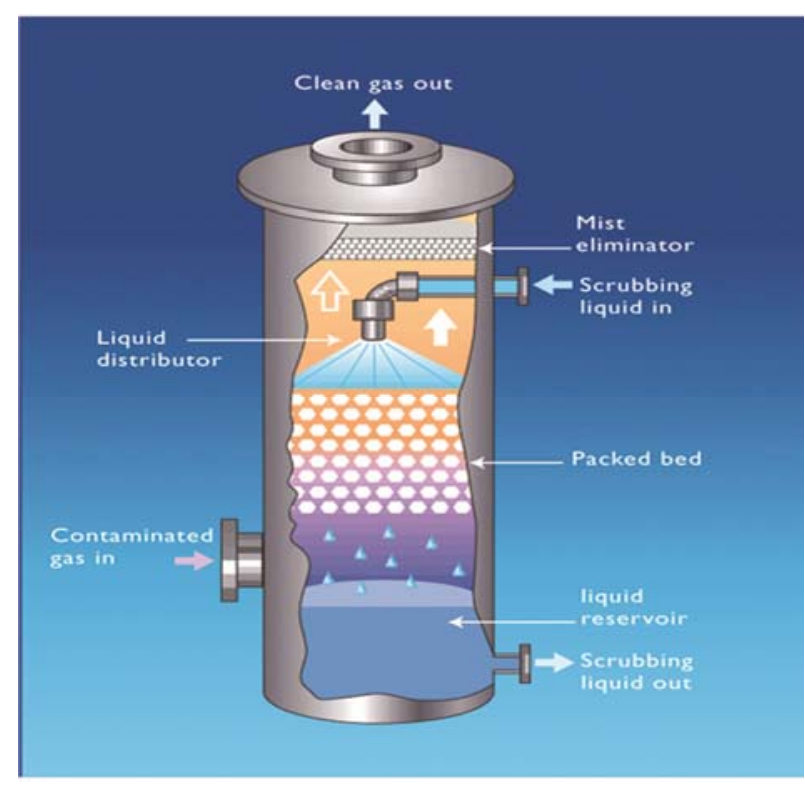

Figure 3. Scrubber 


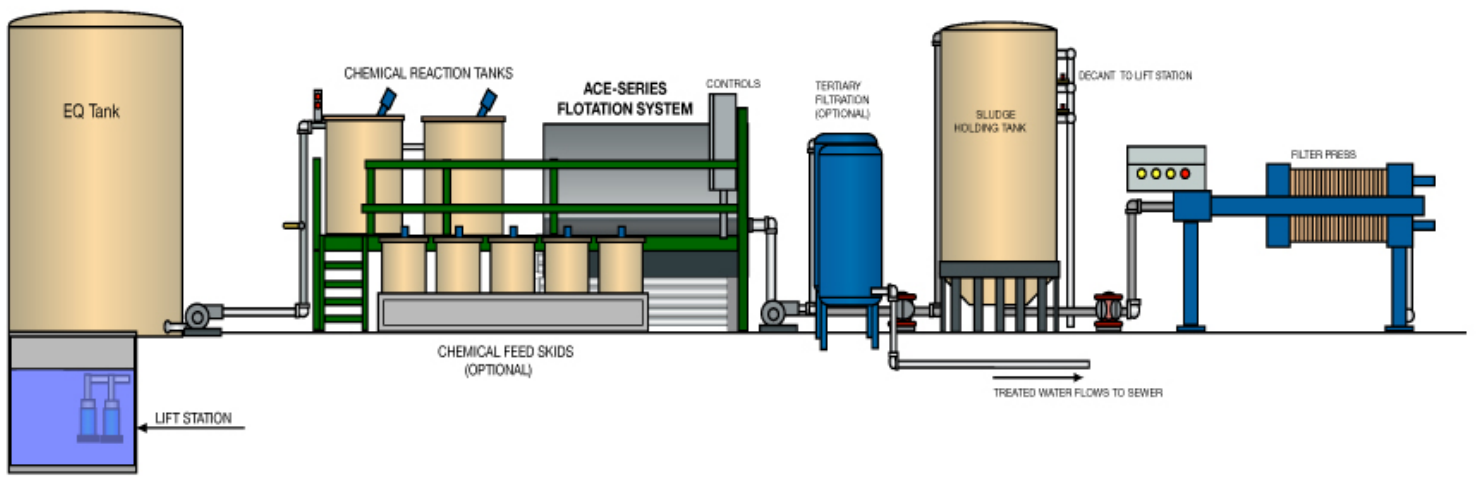

Figure 4. Technological scheme of wastewaters purification in meat industry

\section{CONCLUSION}

The technology of meat processing uses large amounts of high quality water, creating at the same time wastewaters similar in quality to communal wastewaters, and generates large amounts of waste gases and sludge. Thus, the technology of meat processing directly threatens the environment. In this sense, considering the environment protection point of view, it has been pointed out what the critical points in the process are and what the solution for water purification might be.

\section{REFERENCES}

[1] M. Stanisaljević, Tehnologije prerade otpadnih voda i industrijskog opasnog otpada, Visoka tehnička škola strukovnih studija Požarevac, 2010.

[2] Stručni nalaz o ispitivanju kvaliteta otpadnih voda $\mathrm{i}$ emisije zagađujućih materija na emiterima kotlarnice referentne mlekare, Institut za kvalitet radne i životne sredine „1. maj” a.d. Niš

[3] B. Anđelković, I. Krstić, Tehnološki procesi i životna sredina, Jugoslovenski savez inženjera i tehničara zaštite, Fakultet zaštite na radu, Niš, 2002.

[4] A. P. Vanerkar, Sanjeev Satyanarayan, Shanta Satyanarayan, Treatment of Food Processing Industry Wastewater by a Coagulation/ Flocculation Process, International Journal of Chemical and Physical Sciences IJCPS Vol. 2, Special Issue - March 2013 ISSN:2319-6602.

[5] O. Cristian, Wastewater Quality Monitoring in Meat Industry, Analele Universităţii din Oradea, Fascicula: Protecţia Mediului Vol. XV, 2010

\section{BIOGRAPHY}

Vesna Lazarević was born in Niš, Serbia, in 1970.

She is a $\mathrm{PhD}$ of technical sciences environmental protection. She was awarded the title of $\mathrm{PhD}$ at Faculty of Occupational Safety, University of Niš.

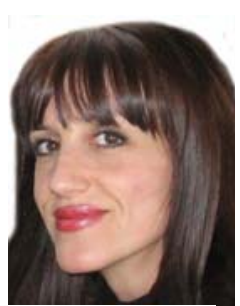

Her main areas of research include waste water, ecotoxicology, etc.

She is currently working in Military Hospital in Nis as a toxicological chemist. She is engaged in testing the quality of drinking water and determining the energy value of one-day military meal. Also, she have cooperated in the development of a number of projects in the field of environmental protection at the Ministry of Defence of the Republic of Serbia.

\section{ANALIZA KRITIČNIH KONTROLNIH TAČAKA U INDUSTRIJI MESA}

\section{Vesna Lazarević, Miodrag Stanisavljević}

Rezime: Tehnologija prerade mesa uključuje procese $i$ operacije koji dovode do pojave emisije štetnih gasova, otpadnih voda i čvrstog otpada. Zbog toga su, radi lakšeg monitoringa i otklanjanja mogućih uzroka, analizirane kritične tačke tehnološkog procesa prerade mesa, a samim tim i posledice neželjenih događaja, a u cilju smanjenja nivoa rizika.

Ključne reči: industrija mesa, otpadne vode, kritične kontrolne tačke. 